Mal J Nutr 27(1): 081-091, 2021

\title{
Energy and protein intakes are associated with stunting among preschool children in Central Jakarta, Indonesia: a case-control study
}

\author{
Sandra Fikawati ${ }^{1 *}$, Ahmad Syafiq ${ }^{1}$, Rienzy Kholifatur Ririyanti ${ }^{2}$ \& Syilga Cahya \\ Gemily $^{2}$
}

${ }^{1}$ Center for Nutrition and Health Studies, Faculty of Public Health University of Indonesia (FPHUI), Depok, West Java, Indonesia; ${ }^{2}$ Department of Public Health Nutrition, FPHUI, Depok, West Java, Indonesia

\begin{abstract}
Introduction: Stunting is a major nutritional problem in Indonesia. The prevalence of stunting in DKI Jakarta province was relatively high at $27.5 \%$ in 2013 and $17.7 \%$ in 2018. This study aims to describe nutrient intakes of children aged 25-30 months and to determine the proportional differences in nutrient intakes between stunting and normal children in Central Jakarta, Indonesia. Methods: A case-control study with a total sample of 121 children aged 25-30 months was conducted in Gambir and Sawah Besar sub-districts, Central Jakarta, where the prevalence of stunting was high. All children were exclusively breastfed for at least four months and had similar socio-economic levels. Data collected included height measurement, questionnairebased interview, and 24-hour food recall. T-test and chi-square test were used to investigate the differences between two groups and logistic regression was used in multivariate analysis. Results: Factors associated with stunting were energy intake $(A O R=6.0 ; 95 \% \mathrm{CI}=1.0-35.0)$ and protein intake $(A O R=4.0 ; 95 \% \mathrm{CI}=1.1-15.5)$ after controlling for fat, carbohydrate, vitamin $\mathrm{C}$, iron, and zinc intakes. The percentage of children with energy intake below the recommendation was much higher in stunted children $(86.1 \%)$ compared to normal children (43.5\%). Similarly, the percentage of children with protein intake below the recommendation was very much higher among stunted children (30.6\%) compared to $8.2 \%$ in normal children. Conclusion: Children who lacked energy and protein intakes were at a higher risk of stunting than children who had sufficient intakes. Macronutrient intakes are important and should be consumed in sufficient quantities every day to prevent stunting.
\end{abstract}

Keywords: Stunting, energy intake, protein intake, preschool children, nutrient intake

\section{INTRODUCTION}

Stunting is a growth and development disorder that occurs in children aged 0-59 months, defined as length/ height-for-age <-2 standard deviations (SD) according to the World Health
Organization (WHO) growth standards (WHO, 2010). According to WHO, stunting is caused by malnutrition, recurrent infections, and inadequate psychosocial stimulation. The shortterm impact of stunting is related to

\footnotetext{
*Corresponding author: Prof. Dr. drg. Sandra Fikawati, MPH

Center for Nutrition and Health Studies, Faculty of Public Health, University of Indonesia,

Building F Level 2, Faculty of Public Health University of Indonesia, Depok, Indonesia.

Tel/fax: (62)-21-7863501; E-mail sandrafikawati@gmail.com, fikawati@ui.ac.id

doi: https: / / doi.org/10.31246/mjn-2020-0074
} 
the reduction of cognitive and physical developments in childhood, while the long-term impact of stunting is related to reduced productivity and work capacity as adults, as well as increased risk of degenerative diseases in the elderly (Hoddinott et al., 2013; Leroy \& Frongillo, 2019).

In Indonesia, stunting is still a major nutritional problem in underfive children. In 2018, the prevalence of stunting in Indonesia was $30.8 \%$, which meant that one in three toddlers in Indonesia was stunted (MOH RI, 2018). The prevalence of stunting in DKI Jakarta province, a capitol city of Indonesia, is also relatively high at $27.5 \%$ in 2013 and $17.7 \%$ in 2018 (MOH RI, 2018). The highest stunting prevalence in DKI Jakarta is occupied by the Central Jakarta area (29.2\%), namely in Gambir and Sawah Besar sub-districts.

Direct factors that influence stunting are infection status and nutrient intake. Nutrient intake in infants, both macronutrient and micronutrient intakes, has a major role in growth (as measured by growth charts) and prevention of growth faltering (Elshazly \& Haridy, 2018; Mzumara et al., 2018). Energy deficits occurring in under-five children would cause growth retardation and loss of fat and muscle (Tessema et al., 2018). Case-control studies on children in Iran and Bangladesh have shown a significant relationship between low carbohydrate intake and stunting (Esfarjani et al., 2013; Iqbal et al., 2019). Research has also shown the relationship between children's fat intake and stunting. Fat is a major component of many hormones, one of which is leptin, which has an effect on bone growth (Briend, Khara \& Dolan, 2015; Mikhail et al., 2013).

Studies show that stunting is influenced by low intake of protein. Protein is significantly related to a child's length or height (Arsenault \& Brown,
2017; Ghosh, 2016; Michaelsen et al., 2019). Chronic protein deficiency in under-five children causes growth to be impeded and becomes lower compared to growth standards. A survey on 75,548 children in 39 low- and middle-income countries showed that children who did not consume protein had a 1.4 times greater risk of stunting (Krasevec et al., 2017).

It is known that some micronutrients (vitamins and minerals) play important roles in the growth and development of children and thus have a relationship with stunting (Iqbal et al., 2019; Mikhail et al., 2013). Many studies have shown the positive contribution of vitamins A and $\mathrm{C}$ to the growth of healthy children (Mora, Iwata \& Andrian, 2008; Pasricha \& Biggs, 2010). Among minerals, studies have shown an association of calcium, iron, and zinc deficiency with stunting (Esfarjani et al., 2013; Iqbal et al., 2019; Pasricha \& Biggs, 2010).

This study aims to describe nutrient intakes of children aged 25-30 months and to determine the proportional differences in nutrient intakes between stunting and normal children aged 25-30 months in Gambir and Sawah Besar sub-districts, Central Jakarta, Indonesia. In the study area, to obtain a sufficient number of children younger than 24-month old with stunting was difficult, therefore, we extended the age range to 30 months old. The percentages of children 25 months old and those older than 25 months were $70.2 \%$ and $29.8 \%$.

\section{MATERIALS AND METHODS}

This study was an observational study with a case-control design using quantitative approach. The study was conducted in Gambir and Sawah Besar sub-districts, Central Jakarta from October to December 2019. These subdistricts have the highest stunting 
prevalences in Central Jakarta District. Respondents were 121 children aged 25-30 months old divided into two groups: 36 children in the case group and 85 children in the control group. To calculate the minimum sample size in this study, the two proportions formula was used. Based on previous research, it was found that the largest number of sample was 35 children. The case-control ratio used to determine the sample was $1: 2$, thus the number of cases was 35 children and number of controls was 70 children. However, when data collection was carried out, there were 36 children who came to the Integrated Health Service Post (Posyandu) for the case group and 85 children for the control group, hence all of them were included as research subjects.

Respondents resided in the Gambir sub-district (townships of Cideng, Petojo Utara, Petojo Selatan, and Duri Pulo) and in the Sawah Besar sub-district (townships of Karang Anyar, Mangga Dua Selatan, Kartini, and Pasar Baru). The case group consisted of children who were stunted at the start of the study based on anthropometric measurements conducted by enumerators, with stunting defined as height-for-age $z$-score $<-2 \mathrm{SD}$, while the control group had children who were not stunted at the time of the study. Matched co-variables were history of exclusive breastfeeding for at least four months and socio-economic level derived from Posyandu data in the same region.

The dependent variable in this study was stunting and the independent variables were macronutrient intakes (energy, protein, fat, and carbohydrate) and micronutrient intakes (vitamin $\mathrm{A}$, vitamin $\mathrm{C}$, calcium, iron, and zinc). Confounding variables in this study were the number of family members, father's education, mother's education, father's occupation, mother's occupation, family income, mother's nutritional knowledge, and infectious diseases.

Primary data collection was carried out by six enumerators with a background in public health nutrition education from the Faculty of Public Health, University of Indonesia. Enumerators were trained for two days with materials related to stunting, interview methods, and data collection mechanism in the field. Nutritional status data based on heightfor-age and weight-for-age were obtained from anthropometric measurements. Measurement of height was carried out twice to get accurate results. The instrument used was a microtoise with duplo measurement. To get accurate results, calibration was carried out before taking measurements. Daily consumption and nutrient intakes were collected using the 24-hour food recall method in the beginning of the study, and food intake data were converted to nutrient intakes using Nutrisurvey (free license).

After data cleaning, univariate and bivariate analyses were conducted using chi-square and independent $t$-test. Variables with $p$-values $<0.25$ in the bivariate analysis were included in the multivariate analysis using logistic regression. Odds ratios (with 95\% confidence intervals, CI) were calculated to determine the relationship between stunting and independent variables. Collinearity and interactions between the independent variables were examined and no collinear variables were found.

Before the interview, respondents were informed about the research and asked about his/her willingness to take part in the research. Respondents were also asked to fill in and sign an informed consent. This research has been approved by the Ethics Commission of the Research and Community Service Institute at Atma Jaya University (Reference number: 1154/III/LPPMPM.10.05/09/2019). 


\section{RESULTS}

Data from a total of 121 respondents aged 25-30 months were successfully collected. The results of the study showed that stunting was more common in boys $(61.1 \%)$. Both stunted $(72.2 \%)$ and non-stunted (69.4\%) children had small family size. Father's education in stunted and non-stunted children were similar, which was high school. Most fathers of both groups had work
(94.4\% in the case group and $96.5 \%$ in the control group), while most mothers do not work $(83.3 \%$ in the case group and $77.6 \%$ in the control group). Both stunted and non-stunted children tended to come from families with low incomes.

Based on the mother's education, there was a significant difference between stunted and non-stunted children, namely $52.8 \%$ of stunted children had

Table 1. Characteristics of children aged 25-30 months in case and control groups

\begin{tabular}{|c|c|c|c|c|}
\hline \multirow[t]{2}{*}{ Variables } & $\begin{array}{l}\text { Case } \\
n=36\end{array}$ & $\begin{array}{c}\text { Control } \\
n=85\end{array}$ & $\begin{array}{c}\text { Total respondents } \\
n=121\end{array}$ & \multirow[t]{2}{*}{ p-value } \\
\hline & \multicolumn{3}{|c|}{$n(\%)$} & \\
\hline \multicolumn{5}{|l|}{ Gender of children } \\
\hline Male & $22(61.1)$ & 37 (43.5) & $59(48.8)$ & \multirow{2}{*}{0.12} \\
\hline Female & $14(38.9)$ & $48(56.5)$ & $62(51.2)$ & \\
\hline \multicolumn{5}{|l|}{ Number of family members } \\
\hline Large (>4 people) & $10(27.8)$ & $26(30.6)$ & $36(29.8)$ & \multirow{2}{*}{0.93} \\
\hline Small ( $\leq 4$ people) & $26(72.2)$ & $59(69.4)$ & $85(70.2)$ & \\
\hline \multicolumn{5}{|l|}{ Father's education } \\
\hline Low, sJunior High School & $12(33.3)$ & $27(31.8)$ & $39(32.2)$ & \multirow{2}{*}{1.00} \\
\hline High, $\geq$ Senior High School & $24(66.7)$ & $58(68.2)$ & $82(67.8)$ & \\
\hline \multicolumn{5}{|l|}{ Mother's education } \\
\hline Low, $\leq$ Junior High School & $19(52.8)$ & $24(28.2)$ & $43(35.5)$ & \multirow[t]{2}{*}{$0.02 *$} \\
\hline High, $\geq$ Senior High School & $17(47.2)$ & $61(71.8)$ & $78(64.5)$ & \\
\hline \multicolumn{5}{|l|}{ Father's occupation } \\
\hline Does not work & $2(5.6)$ & $3(3.5)$ & $5(4.1)$ & \multirow[t]{2}{*}{0.63} \\
\hline Work & $34(94.4)$ & $82(96.5)$ & $116(95.9)$ & \\
\hline \multicolumn{5}{|l|}{ Mother's occupation } \\
\hline Does not work & $30(83.3)$ & $66(77.6)$ & $96(79.3)$ & \multirow[t]{2}{*}{0.65} \\
\hline Work & $6(16.7)$ & $19(22.4)$ & $25(20.7)$ & \\
\hline \multicolumn{5}{|l|}{ Family income } \\
\hline$<$ Minimum salary level & $26(72.2)$ & $47(55.3)$ & $73(60.3)$ & \multirow[t]{2}{*}{0.12} \\
\hline$\geq$ Minimum salary level & $10(27.8)$ & $38(44.7)$ & $48(39.7)$ & \\
\hline \multicolumn{5}{|l|}{ Mother's nutrition knowledge } \\
\hline Low & $14(38.9)$ & $27(31.8)$ & 41 (33.9) & \multirow[t]{2}{*}{0.58} \\
\hline High & $22(61.1)$ & $58(68.2)$ & $80(66.1)$ & \\
\hline \multicolumn{5}{|l|}{ ARI history } \\
\hline Yes & $9(25.0)$ & $18(21.2)$ & $27(22.3)$ & \multirow[t]{2}{*}{0.82} \\
\hline No & $27(75.0)$ & $67(78.8)$ & $94(77.7)$ & \\
\hline \multicolumn{5}{|l|}{ Diarrhea history } \\
\hline Yes & $6(16.7)$ & $8(9.4)$ & $14(11.6)$ & \multirow[t]{2}{*}{0.35} \\
\hline No & $30(83.3)$ & 77 (90.6) & $107(88.4)$ & \\
\hline
\end{tabular}

*Statistically significant at $p$-value $\leq 0.05$ 


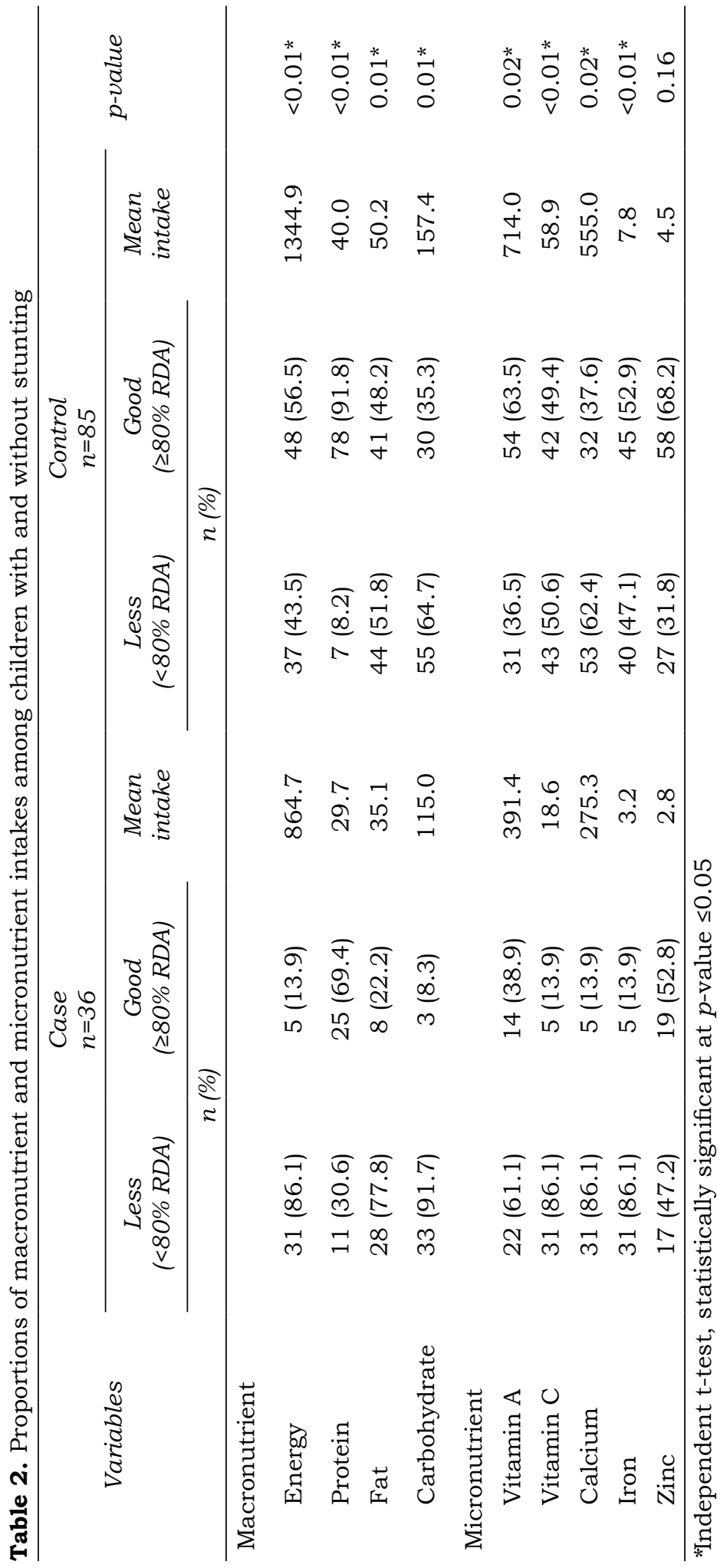




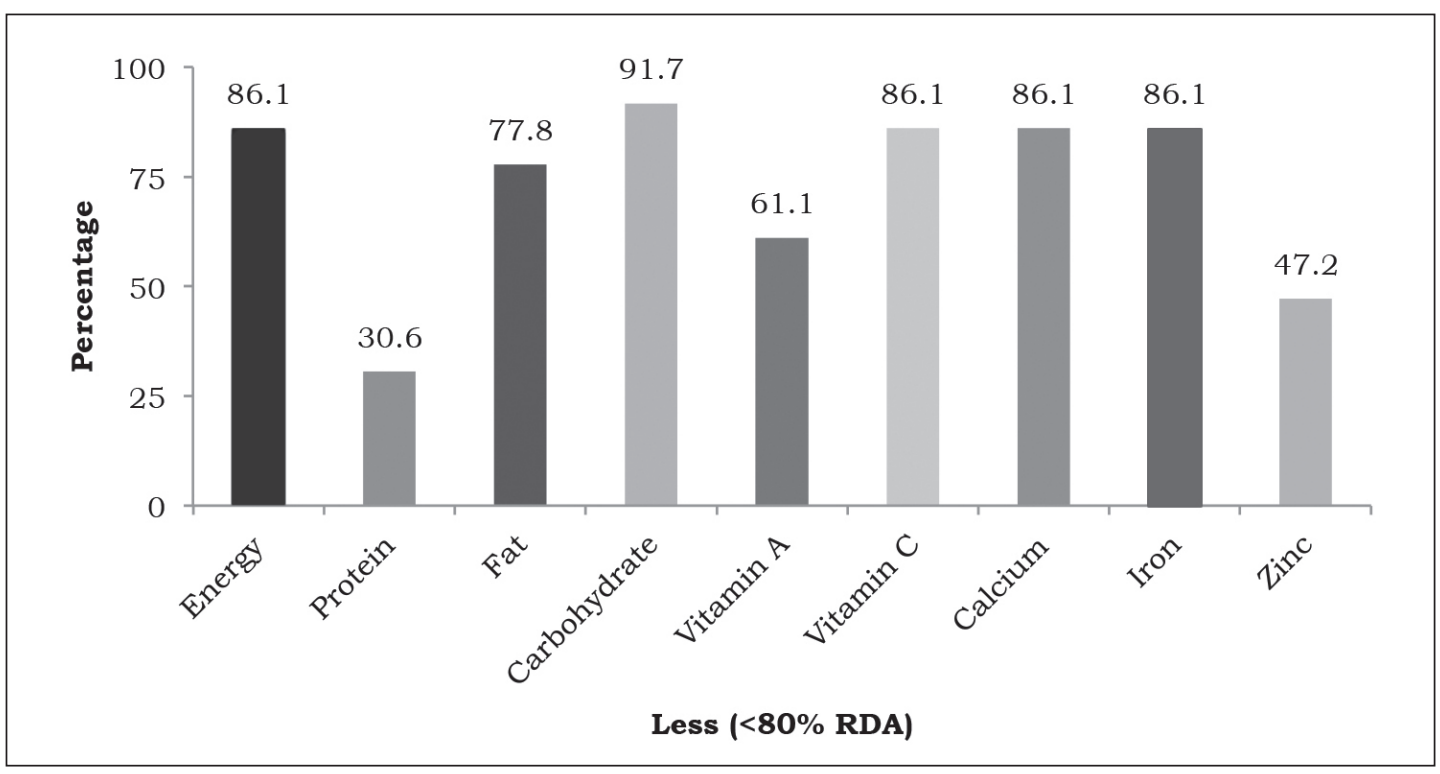

Figure 1. Percentages of macronutrients and micronutrients adequacy in case group

mothers with low education, while in non-stunted children, most of the mothers had higher education (71.8\%). In terms of history of illness, there was no significant difference between the two groups. Most stunted and nonstunted children did not have a history of infectious diseases, either acute respiratory infection (ARI) or diarrhoea. Stunted children tended to have mothers with low nutritional knowledge compared to non-stunted children. The characteristics of the children according to case and control groups can be seen in Table 1.

This study showed that majority of stunted children consumed energy, fat, carbohydrates, and protein lesser than the recommended nutritional adequacy, namely $86.1 \%, \quad 77.8 \%$, $91.7 \%$, and $30.6 \%$, respectively (Table $3)$. In comparison, the percentages of non-stunted children with intakes less than the recommendation were $43.5 \%$, $51.8 \%, 64.7 \%$, and $8.2 \%$, respectively. The average energy intake of stunted children was significantly lower $(865$ kcal/day) compared to the average energy intake of non-stunted children (1345 kcal/day). Similarly, the average protein intake of stunted children was lower (29.7 g/day) compared to nonstunted children (40.0 g/day). Both fat and carbohydrate intakes were also observed to be lower among stunted children (35.1 g/day and $115.0 \mathrm{~g} /$ day) compared to non-stunted children (50.2 $\mathrm{g} /$ day and $157.4 \mathrm{~g} /$ day) (Table 2).

The percentages of stunted children with micronutrient intakes (vitamin A, vitamin $\mathrm{C}$, calcium, iron, and zinc) below the recommended nutritional adequacy were $61.1 \%$ for vitamin A, $86.1 \%$ for vitamin $\mathrm{C}$, calcium and iron, and $47.2 \%$ for zinc. Meanwhile, the percentages of non-stunted children with micronutrient intakes (vitamin $\mathrm{A}$, vitamin $\mathrm{C}$, calcium, iron, and zinc) below the recommended nutritional adequacy were $36.5 \%$ for vitamin A, $50.6 \%$ for vitamin C, $62.4 \%$ for calcium, $47.1 \%$ for iron, and $31.8 \%$ for zinc. Adequacy of micronutrients in non-stunted children exceeded the recommended adequacy of nutrients, 


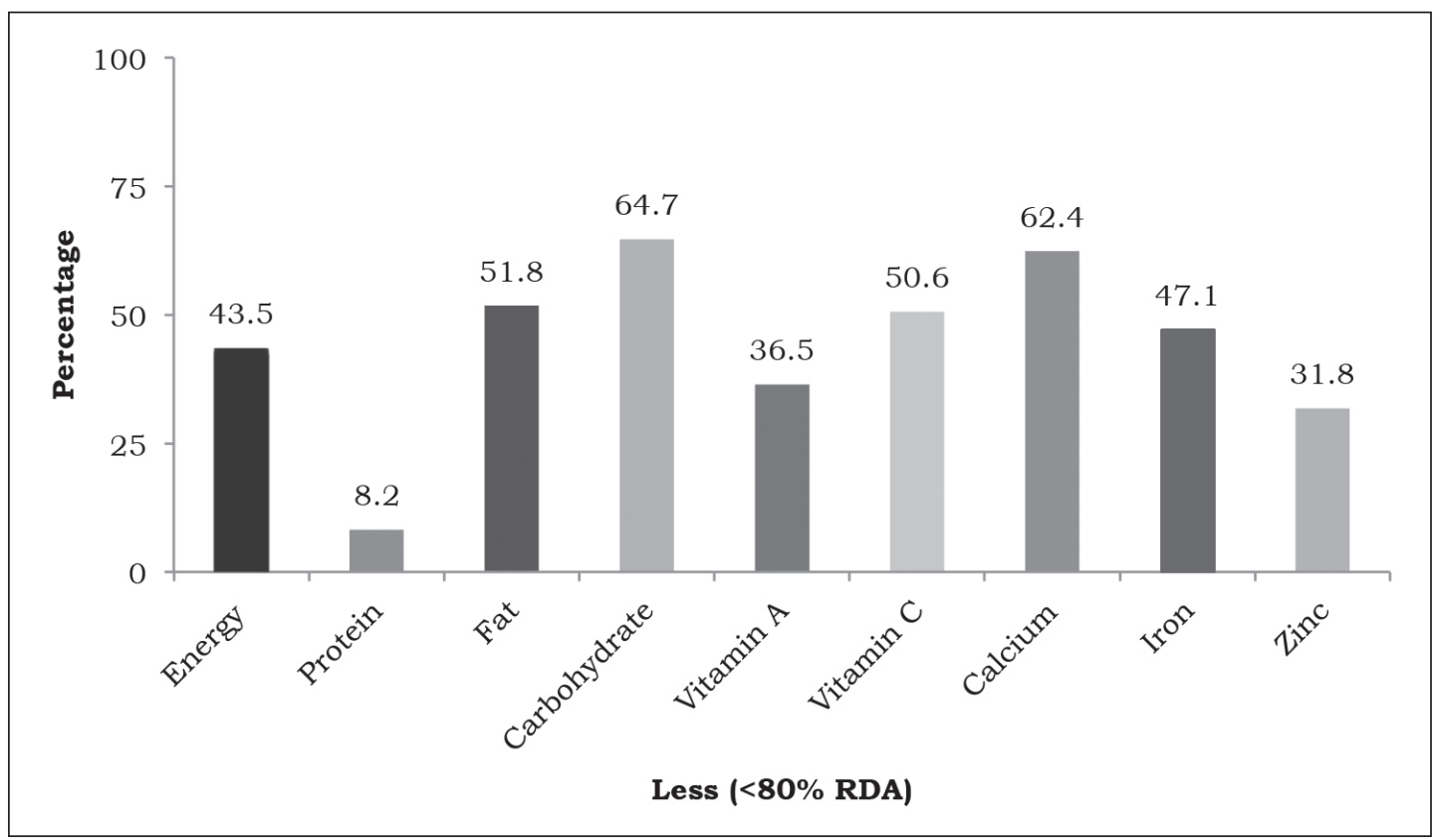

Figure 2. Percentages of macronutrients and micronutrients adequacy in control group

except for calcium, where non-stunted children consumed an average of 555.0 $\mathrm{mg} /$ day and stunted children were significantly lower at only $275.3 \mathrm{mg} /$ day (the recommendation is $650.0 \mathrm{mg} /$ day). The proportions of macronutrient and micronutrient intakes among children with and without stunting are displayed in Table 2. Percentages of macronutrients and micronutrients adequacy in case and control groups are presented in Figure 1 and Figure 2, respectively.

Nine nutrients included in the multivariate analysis were energy, protein, fat, carbohydrate, vitamin $\mathrm{A}$, vitamin $\mathrm{C}$, calcium, iron, and zinc intakes. The analysis showed that factors associated with stunting were energy intake $(A O R=6.0 ; 95 \% \mathrm{CI}=1.0-$ 35.0) and protein intake $(A O R=4.0 ; 95 \%$ $\mathrm{CI}=1.1-15.5) \quad$ (Table 3). Children with energy intake less than recommendation had six times greater odds for stunting than those with sufficient energy intake. Children whose protein intake was less than recommended had four times greater odds for stunting than those with sufficient protein intake.

\section{DISCUSSION}

In terms of demographic and socioeconomic characteristics, the two groups in this study were relatively similar. Significant difference was found only in maternal education, whereby stunted children had mothers with lower levels of education than non-stunted children. These results are similar to other studies in Nigeria and Nairobi, which reported that low-educated mothers have limited knowledge, especially regarding child feeding, food choices, and health seeking practices, which consequently contribute to stunting (Abuya, Ciera \& Kimani-murage, 2012; Fadare et al., 2019).

Results of this study indicated that children with energy intake less than recommendation have six times greater risk of stunting than children whose 
Table 3. Multivariate analysis of factors associated with stunting

\begin{tabular}{|c|c|c|c|c|c|}
\hline \multirow[t]{2}{*}{ Variables } & $\begin{array}{l}\text { Case } \\
n=36\end{array}$ & $\begin{array}{c}\text { Control } \\
n=85\end{array}$ & $\begin{array}{c}\text { Total respondents } \\
n=121\end{array}$ & \multirow[t]{2}{*}{ p-value } & \multirow[t]{2}{*}{$\begin{array}{c}\text { Adjusted OR } \\
(95 \% \text { CI) }\end{array}$} \\
\hline & \multicolumn{3}{|c|}{$n(\%)$} & & \\
\hline \multicolumn{6}{|l|}{ Energy intake } \\
\hline Less $(<80 \%$ RDA) & $31(86.1)$ & 37 (43.5) & $68(56.2)$ & \multirow{2}{*}{$0.05^{*}$} & \multirow{2}{*}{$6.0(1.0-35.0)$} \\
\hline Good ( $\geq 80 \%$ RDA $)$ & 5 (13.9) & $48(56.5)$ & $53(43.8)$ & & \\
\hline \multicolumn{6}{|l|}{ Protein intake } \\
\hline Less (<80\% RDA) & 11 (30.6) & $7(8.2)$ & $18(14.9)$ & \multirow{2}{*}{$0.04^{*}$} & \multirow{2}{*}{$4.0(1.1-15.5)$} \\
\hline Good ( $\geq 80 \%$ RDA) & $25(69.4)$ & $78(91.8)$ & $103(85.1)$ & & \\
\hline \multicolumn{6}{|l|}{ Fat intake } \\
\hline Less (<80\% RDA) & $28(77.8)$ & $44(51.8)$ & $72(59.5)$ & \multirow{2}{*}{0.25} & \multirow{2}{*}{$0.4(0.1-2.0)$} \\
\hline Good ( $\geq 80 \%$ RDA) & $8(22.2)$ & $41(48.2)$ & 49 (40.5) & & \\
\hline \multicolumn{6}{|l|}{ Carbohydrate intake } \\
\hline Less $(<80 \%$ RDA) & $33(91.7)$ & $55(64.7)$ & $88(72.7)$ & \multirow{2}{*}{0.52} & \multirow{2}{*}{$1.8(0.3-10.1)$} \\
\hline Good $(\geq 80 \% \mathrm{RDA})$ & $3(8.3)$ & $30(35.3)$ & $33(27.3)$ & & \\
\hline \multicolumn{6}{|l|}{ Vitamin $\mathrm{C}$ intake } \\
\hline Less (<80\% RDA) & $31(86.1)$ & 43 (50.6) & $74(61.2)$ & \multirow{2}{*}{0.11} & \multirow{2}{*}{$2.7(0.8-9.1)$} \\
\hline Good ( $\geq 80 \%$ RDA) & 5 (13.9) & $42(49.4)$ & $47(38.8)$ & & \\
\hline \multicolumn{6}{|l|}{ Iron intake } \\
\hline Less $(<80 \%$ RDA) & $31(86.1)$ & $40(47.1)$ & $71(58.7)$ & \multirow{2}{*}{0.09} & \multirow{2}{*}{$3.2(0.8-11.9)$} \\
\hline Good $(\geq 80 \% \mathrm{RDA})$ & 5 (13.9) & 45 (52.9) & $50(41.3)$ & & \\
\hline \multicolumn{6}{|l|}{ Zinc intake } \\
\hline Less (<80\% RDA) & $17(47.2)$ & $27(31.8)$ & $44(36.4)$ & \multirow{2}{*}{0.12} & \multirow{2}{*}{$0.4(0.1-1.3)$} \\
\hline Good ( $\geq 80 \%$ RDA) & $19(52.8)$ & $58(68.2)$ & 77 (63.6) & & \\
\hline
\end{tabular}

* Multiple logistic regression, statistically significant at $p \leq 0.05$

energy intake was sufficient $(A O R=6.0$; 95\% $C I=1.1-40.0)$. These results are in line with a randomised controlled trial study conducted by Tessema et al. (2018) in rural Ethiopian children aged 6-35 months $(n=873)$, who reported that stunted children had significantly lower daily energy intakes than non-stunted children (Tessema et al., 2018). Several other studies also reported similar findings that there was significant relationship between energy intake and stunting (Abebe, Haki \& Baye, 2018; Iqbal et al., 2019).

This study also revealed that children with protein intake less than recommendation had four times greater risk of stunting than children whose energy intake was sufficient $(A O R=4.0$; $95 \% \quad C I=1.1-15.5)$. A study of 873 children in Ethiopia showed that a lack of protein intake, both in quality and quantity, has a significant relationship with stunting. Intakes of tryptophan, protein, and energy, as well as serum levels of tryptophan and insulin-like growth factor 1 (IGF-1) in serum, are positively correlated with the linear growth of children (Tessema et al., 2018). Stunting has a close relationship with protein intake that functions to stimulate insulin in IGF-1 (Millward, 2017; Dror \& Allen, 2011). In a study in Bogor District, Indonesia, Fikawati et al. (2019) reported that toddlers with inadequate protein intake were almost three times more likely to suffer from stunting compared to children with adequate protein intake. Another study in Bogor found that the majority of children $(87.0 \%)$ consumed grains, such as rice and bread, while consumption of 
eggs, legumes, and animal source foods were low (Trisasmita et al., 2020).

There were significant relationships between energy and protein intakes with stunting after controlling for fat, carbohydrate, vitamin $\mathrm{C}$, iron, and zinc intakes. The results of this study are similar to studies among toddlers aged 25-60 months in Mangkung Village, District of Central Lombok (Anshori, Sutrisna, Fikawati, 2020), which found that among 372 toddlers randomly sampled from Posyandu, macronutrient intakes (energy and protein) had significant relationships with stunting incidence.

The results implied that macronutrients are most important to overcome stunting in this population. They support the possible neglect of macronutrient deficiencies among children in developing countries amid the dominance of micronutrient deficiency narratives. Semba (2016) pointed out that protein is the missing essential nutrient to growth in the diet, meanwhile micronutrients supplementation showed limited or no efficacy towards stunting (Semba, 2016; Stammers et al., 2015; Mayo-Wilson et al., 2014). Iqbal et al. (2019) found that in low-resource settings, global deoxyribonucleic acid (DNA) methylation was higher among children with low protein, carbohydrate and energy intakes. Stunted children has a higher DNA methylation. This study therefore emphasises the importance of macronutrient sufficiency in preventing stunting among children 2-3 years old.

Low animal source protein intake may relate to the higher prevalence of stunting in Indonesia. Sjarif, Yuliarti \& Iskandar (2019) reported that two protein sources had significant associations with stunting, namely growing-up milk and red meat products. The national data on individual food consumption revealed that animal source protein consumption among under-five children was very low, i.e., $39.8 \mathrm{~g} /$ day of fish, $20.1 \mathrm{~g} /$ day of eggs, $29.4 \mathrm{~g} /$ day of meat, and $22.6 \mathrm{~g} /$ day of fresh milk (MOH RI, 2014).

The lack of significance between micronutrient and stunting in this study could be caused by several factors. The data showed that micronutrient intakes were closer to recommendation than macronutrient intakes. Moreover, micronutrient serum level was not associated with DNA methylation in the Iqbal study. This could be related to low protein intake, level of body stores, infection status, and bioavailability (Iqbal et al., 2019). This result does not undermine the importance of micronutrients in relation to their roles in linear growth, rather it shows that emphasis on micronutrients booming in recent years should be balanced by re-establishing the importance of macronutrients.

This study has several limitations. Firstly, it cannot ascertain a causal relationship due to temporal factors in the case-control study design. Secondly, this study did not measure some variables associated with the linear growth of children such as environmental sanitation and hygiene. Thirdly, there is a possibility of distorted reporting, which is a potential problem in all dietary assessment methods, and it is not known to what extent parents reported their child's food intake, as well as neglected or discounted for leftovers. We assumed that the data reflected daily consumption since the variety of foods and beverages at this age range is limited, and also that the socioeconomic levels of the subjects in these two groups were similar. Fourthly, there is a possibility that sample size was too small as indicated by the large range of confidence interval. Thus, future studies should consider to add more samples.

Based on the results of this study, a priority should be given to nutritional programmes that emphasise increasing 
energy and protein intakes. The effects of consumption of high-quality energy and protein foods, especially animal protein, in supporting the linear growth of children must be further investigated with the design of longitudinal intervention studies. Through robust longitudinal studies, it can be ascertained that the contribution of nutrients, both macroand micronutrients, in the increase of linear growth among children. The amount of energy and protein intakes must be calculated by considering various factors beforehand, such as infectious diseases and the nutritional condition of the child.

\section{CONCLUSION}

The results showed that after controlling for fat, carbohydrate, vitamin $\mathrm{C}$, calcium and zinc intakes, energy and protein intakes were factors associated with stunting among children aged 25-30 months in Gambir and Sawah Besar sub-districts, Central Jakarta. Children whose energy and protein intakes were below recommendation had six and four times, respectively, higher risk of stunting than children with sufficient intakes. Macronutrients are important and should be consumed in sufficient quantities every day to prevent stunting.

\section{Acknowledgement}

The authors thank the Directorate of Research and Community Service at the University of Indonesia and the Directorate General of Strengthening Research and Development of the Ministry of Research, Technology and Higher Education of the Republic of Indonesia for supporting the study in accordance with the Agreement Funding for Research and Community Service NKB -1582/ UN2.R3.1/HKP.05.00/2019 Fiscal Year 2019.

\section{Authors' contributions}

SF, principal investigator, conceptualised and designed the study, prepared draft of the manuscript, reviewed and revised the manuscript; AS, conducted data analysis and interpretation; RRK, collected and analysed data, and SCG, analysed data and added new related references for manuscript.

\section{Conflict of interest}

No conflict of interest.

\section{References}

Abebe Z, Haki GD \& Baye K (2018). Simulated effects of home fortification of complementary foods with micronutrient powders on risk of inadequate and excessive intakes in West Gojjam, Ethiopia. Matern Child Nutr 14(1):1-9.

Abuya BA, Ciera J \& Kimani-murage E (2012). Effect of mother's education on child's nutritional status in the slums of Nairobi. BMC Pediatr 12(80):1-10.

Anshori LM, Sutrisna B \& Fikawati S (2020). Relationship energy and protein intake with the incidence of stunting among toddler aged (25-60 months) in Mangkung village, District of Central Lombok. Indian $J$ Public Health 11(3):1593-1598.

Arsenault JE \& Brown KH (2017). Effects of protein or amino-acid supplementation on the physical growth of young children in lowincome countries. NutrRev 75(9):699-717.

Briend A, Khara T \& Dolan C (2015). Wasting and stunting-similarities and differences: policy and programmatic implications. Food Nutr Bull 36(1):S15-S23.

Dror DK \& Allen LH (2011). The importance of milk and other animal-source foods for children in low-income countries. Food Nutr Bull 32(3):227-243.

Elshazly RMSM \& Haridy LAE (2018). Catch up and control of malnutrition in stunted children under the age of 5 years by using recent recipe of nutrition. EC Nutr 13(4):193-199.

Esfarjani F, Roustaee R, Mohammadi-Nasrabadi F\& Esmaillzadeh A (2013). Major dietary patterns in relation to stunting among children in Tehran, Iran. J Health Popul Nutr 31(2):202210.

Fadare O, Mavrotas G, Akerele D \& Oyeyemi M (2019). Micronutrient-rich food consumption, intra-household food allocation and child stunting in rural Nigeria. Public Health Nutr 22(3):444-454.

Fikawati S, Adhi EK, Syafiq A \& Bakara SM (2019). Age of milk introduction is a dominant factor of stunting among toddlers aged 24 months in Bogor district: a cross-sectional study. Pakistan J Nutr 18(10):969-976.

Ghosh S (2016). Protein Quality in the First Thousand Days of Life. Food Nutr Bull 37(Supplement 1):S14-S21. 
Hoddinott J, Behrman JR, Maluccio JA, MelgarP, Quisumbing AR, Ramirez-Zea M, Manuel S, Aryeh D, Yount KM \& Martorell R (2013). Adult consequences of growth failure in early childhood. Am J ClinNutr 98(5):1170-1178.

Iqbal MS, Rahman S, Haque MA, Bhuyan MJ, Faruque ASG \& Ahmed T (2019). Lower intakes of protein, carbohydrate, and energy are associated with increased global DNA methylation in 2- to 3-year-old urban slum children in Bangladesh. Matern Child Nutr 15(3): 1-9.

Krasevec J, An X, Kumapley R, Bégin F \& Frongillo EA (2017). Diet quality and risk of stunting among infants and young children in lowand middle-income countries. Matern Child Nutr13(S2):1-11.

Leroy JL \& Frongillo EA (2019). Perspective: what does stunting really mean? A critical review of the evidence. AdvNutr10(2):196-204.

Mayo-Wilson E, Junior JA, Imdad A, Dean S, Chan XHS, Chan ES, Jaswal A, \& Bhutta ZA (2014). Zinc supplementation for preventing mortality, morbidity, and growth failure in children aged 6 months to 12 years of age. Cochrane Database of Systematic Reviews 2014, Issue 5.

Michaelsen KF, Hoppe C, Roos N, Kaestel P, Sougaard M, Lauritzen L, Molgaard C, Girma $\mathrm{T} \&$ Friis H (2019). Choice of foods and ingredients for moderately malnourished children 6 months to 5 years of age. Food NutrBull 30(3):S343-S404.

Mikhail WZA, Sobhy HM, El-sayed HH, Khairy SA, Salem HYHA \& Samy MA (2013). Effect of nutritional status on growth pattern of stunted preschool children in Egypt. Acad JNutr 2(1):19.

Millward DJ (2017). Nutrition, infection and stunting: The roles of deficiencies of individual nutrients and foods, and of inflammation, as determinants of reduced linear growth of children. Nutr Res Rev 30(1):50-72.

MOH RI (2018). Main RISKESDAS 2018 Results. Ministry of Health Republic of Indonesia, Jakarta.
MOH RI (2014). Individual Food Consumption Survey in Total Dietary Study 2014. Ministry of Health Republic of Indonesia, Jakarta.

Mora JR, Iwata M \& Andrian UH Von (2008). Vitamin effects on the immune system: vitamin $\mathrm{A}$ and $\mathrm{D}$ take centre stage. Nature Review Immunology 8(9):685-698.

Mzumara B, Bwembya P, Halwiindi H, Mugode R \& Banda J (2018). Factors associated with stunting among children below five years of age in Zambia: evidence from the 2014 Zambia demographic and health survey. BMC Nutr $4(1): 1-8$.

Pasricha SR \& Biggs BA (2010). Undernutrition among children in South and South-East Asia. $J$ Paediatr Child Health 46(9):497-503.

Sjarif DR, Yuliarti K \& Iskandar WJ (2019). Daily consumption of growing-up milk is associated with less stunting among indonesian toddlers. Med J Indones 28(1):70-76.

Semba RD (2016). The Rise and fall of protein malnutrition in global health. Ann Nutr Metab 69:79-88.

Stammers AL, Lowe NM, Medina MW, Patel S, Dykes F, Pérez-Rodrigo C, Serra-Majam L, Nissensohn M \& Moran VH (2015). The relationship between zinc intake and growth in children aged 1-8 years: a systematic review and meta-analysis. Eur J Clin Nutr 69:147-153.

Tessema M, Gunaratna NS, Brouwer ID, Donato $\mathrm{K}$, Cohen JL, Mcconnell M, Belachew T, Belayneh D \& Groote HDe (2018). Associations among high-quality protein and energy intake, serum transthyretin, serum amino acids and linear growth of children in Ethiopia. Nutrients 10(1776):1-17.

Trisasmita L, Sudiarti T, Sartika RAD \& Setiarini A (2020). Identification of dietary diversity associated with stunting in Indonesia. Mal $J$ Nutr 26(1):085-092.

WHO (2010). Nutrition Landscape Information System (NLIS): Country Profile Indicators: Interpretation Guide. World Health Organization, Geneva. 